\title{
PENERAPAN TEKNIK MIND MAPPING DALAM PENGAJARAN PENULISAN ESAI SASTRA BERBAHASA INGGRIS
}

\author{
Afina Murtiningrum \\ Fakultas Bahasa dan Ilmu Komunikasi UNISSULA Semarang \\ afina@unissula.ac.id
}

\begin{abstract}
Some difficulties faced by students in writing a literary essay are the abilities to find the appropriate topics for the essay, develop the content paragraph structure and length in writing, and achieve cohesion and coherence. This research aims at implementing mind-mapping technique in writing a literary essay. The subjects of this research were the third semester students of English Literature Study Program at Sultan Agung Islamic University in Semarang. Observation and documentation were used to collect data in which the coherence and cohesion were analyzed. The findings show that mind-mapping technique gives significant impact to students' abilities in writing a literary essay.
\end{abstract}

Keywords : mind-mapping, paragraph structure, coherence, cohesion

\section{PENDAHULUAN}

Menulis merupakan sarana berkomunikasi untuk menyampaikan ide, gagasan atau pikiran. Supaya ide, gagasan dan pikiran dapat tersampaikan, dibutuhkan suatu ketrampilan menulis.. Ketrampilan menulis merupakan suatu ketrampilan yang kompleks sifatnya karena dalam menulis seorang penulis tidak hanya dituntut untuk menuangkan ide-ide atau gagasannya ke dalam bahasa tulis yang baik akan tetapi bahasa tulis tersebut harus mampu dipahami dan diterima dengan baik oleh pembaca. Untuk mencapai hal tersebut, ketrampilan seorang penulis dalam menuangkan gagasannya secara kohesif dan koheren sangatlah diperlukan. Kaidah-kaidah pengorganisasian wacana tulis sangat perlu untuk dikuasai oleh seorang penulis di samping latihan dan praktek menulis secara berkesinambungan dan terus menerus. Keterampilan menulis ini perlu dimiliki oleh semua orang, tidak terkecuali mahasiswa.

Kaidah-kaidah pengorganisasian dan latihan terus menerus yang didapatkan mahasiswa di dalam proses pembelajaran diharapkan dapat menunjang baik tidaknya tulisan yang dihasilkan meskipun adakalanya proses pembelajaran yang berupa latihan berkesinambungan tidak menjamin secara optimal mahasiswa dapat menghasilkan tulisan yang baik. Permasalahan umum yang dihadapi yaitu kurang mampunya mahasiswa dalam menuangkan 
gagasan kreatifnya ke dalam sebuah tulisan. Selain itu kendala yang sering terjadi adalah lamanya waktu yang dibutuhkan mahasiswa untuk memikirkan topik yang hendak disampaikan. Mahasiswa sering kali mengeluhkan tentang sulitnya menentukan ide pokok tulisan dan kemudian menuangkan ide tersebut ke dalam bentuk karangan yang efektif agar pesan tersampaikan Kendala lain yang juga dihadapi adalah tidak terbiasanya mahasiswa membuat kerangka karangan (outline) sehingga banyak waktu terserap dengan sia-sia karena mereka tidak tahu harus memulai menulis dari mana.

Penerapan teknik mind mapping dalam penulisan esai telah banyak di teliti. Dijelaskan oleh McGriff dalam Rafidah Abdul Karim, dkk (2016) bahwa teknik mind maping adalah suatu alat yang sangat membantu siswa dalam memecahkan masalah yang berkaitan dengan pengorganisasian ide dan pikiran. Mind mapping membantu mengorganiasikan dan mengingat informasi tertulis, menemukan permasalahan dalam esai, merencanakan dan mengevaluasi tulisan :"mind mapping is seen as a powerful tool to help students overcome problems with the organization of their ideas and thoughts. In addition, it was also found that relating images to concepts is a creative task which requires thinking instead of memorizing".

Berdasarkan permasalahan tersebut di atas, penelitian ini mencoba memberikan alternatif solusi untuk mengatasi kesulitan mahasiswa dalam menuangkan dan mengorganisasikan idenya dalam suatu karangan yang baik dan koheren sehingga pesan tersampaikan kepada pembaca. Solusi yang ditawarkan berupa pengajaran menulis esai dengan teknik mindmapping. Melalui teknik mind-mapping diharapkan mahasiswa mampu dengan lebih mudah untuk menentukan ide pokok pikiran serta mengembangkan atau mengorganisasikan ide tersebut menjadi suatu tulisan yang koheren.

\subsection{MENULIS KARYA ILMIAH BERUPA ESAI SASTRA}

Karya ilmiah merupakan salah satu sarana penyebaran ilmu pengetahuan dan teknologi (Iptek). Dalam dunia akademik, khususnya perguruan tinggi, menulis karya ilmiah merupakan sebuah kewajiban. Ketrampilan menulis karya ilmiah berupa esai mempunyai kedudukan yang sangat penting dan strategis karena melalui menulis esai mahasiswa dapat mengungkapkan gagasan dan masalah pada orang lain (Pujiono, 148). Tujuan dari perkuliahan menulis esai adalah memperoleh pengetahuan, wawasan, dan kemampuan penulisan. Akan tetapi, tujuan perkuliahan tesebut tidak mudah untuk dicapai. Dalam proses perkuliahan, ditemukan banyak 
permasalahan. Permasalahan itu berupa kesulitan menemukan ide, kesulitan menuangkan gagasan, kesalahan bahasa, dan kurangnya motivasi belajar mahasiswa. Kesulitan-kesulitan tersebut, jika tidak segera diatasi akan mengakibatkan kendala berkelanjutan dalam proses perkuliahan mata kuliah menulis lainnya.

Berkaitan dengan karya ilmiah berupa esai sastra, pada dasarnya struktur esai sastra sama seperti esai pada umumnya yang terdiri dari pendahuluan, pembahasan dan simpulan. Pendahuluan esai sastra berisikan kalimat pembuka secara umum tentang topik yang akan ditulis dalam esai yang biasa disebut dengan hook, beberapa kalimat tentang karya sastra yang ditulis (judul karya sastra, pengarang dan cerita singkat tentang karya sastra tesebut) dan pernyataan tesis (tesis statement) yang berisikan problem yang ingin ditulis ke dalam beberapa paragraf pembahasan. Pembahasan berisikan beberapa kalimat pendukung topik tulisan (supporting sentences) yang berupa contoh dari karya sastra maupun kutipan dari referensi. Simpulan berisikan konfirmasi kembali tentang topik yang ditulis (Rahman dan Chan, 98-99).

\subsection{PENGAJARAN MENULIS ESAI SASTRA BERBAHASA INGGRIS}

Belajar bahasa Inggris bukan merupakan hal yang mudah karena Bahasa Inggris merupakan bahasa asing bagi mahasiswa Fakultas Bahasa Unissula Semarang. Terlebih lagi apabila bahasa Inggris tidak sering digunakan dalam kegiatan sehari-hari. Tetapi karena bahasa Inggris merupakan bahasa Internasional maka belajar bahasa Inggris merupakan suatu kewajiban.. Hal ini kemudian menjadikan tantangan bagi guru dan dosen untuk mengajarkan bahasa Inggris dengan baik (Harmer dalam Wigati, 2015 : 26). Satu hal yang masih menjadikan tantangan terbesar bagi guru dan dosen adalah pengajaran menulis. Menurut Hyland dalam Wigati (2015), dalam pengajaran menulis bahasa Inggris, ada beberapa hal penting yang harus dipelajari dalam proses menulis, diantaranya menitikberatkan pada struktur bahasa, pada fungsi teks, pada cara pengekspresian diri secara kreatif dan menitikberatkan pada proses menulis. Sauasana pembelajaran yang kondusif dan menyenangkan juga menjadi salah satu aspek yang mempengaruhi mahasiswa untuk dapat berpikir kreatif dan sistematis. Di samping itu, pemilihan metode dan teknik mengajar menulis yang tepat juga dapat membantu memotivasi mahasiswa agar dapat berpikir kreatif dan sistematis.

\subsection{PENGAJARAN MENULIS ESAI BERBAHASA INGGRIS DENGAN TEKNIK MIND MAPPING}

PENERAPAN TEKNIK MIND MAPPING DALAM PENGAJARAN PENULISAN ESAI SASTRA BERBAHASA INGGRIS-AFINA MURTININGRUM-DBB V14 N2 JULI 2019 
Menulis esai menuntut sejumlah kemampuan dan ketrampilan untuk menghasilkan suatu tulisan yang baik. Mengembangkan esai pun bukan hal yang mudah meskipun ide pokok dan tambahan bahan tulisan berupa referensi pun sudah terkumpul. Pengajaran menulis esai pada umumnya hanya terpaku pada pedoman yang berupa silabus. Hal ini tidak memacu mahasiswa untuk menggunakan kreativitasnya dalam mengembangkan ide gagasannya.

Beranjak dari permasalahan di atas, pengajaran menulis esai dengan menerapkan teknik mind mapping dapat membantu pembelajaran menulis dalam proses pengembangan ide dan pengorganisasian tulisan. Pengajaran menulis esai dengan menerapkan teknik mind mapping telah banyak di teliti. Dijelaskan oleh McGriff dalam Rafidah Abdul Karim, dkk (2016) bahwa teknik mind maping adalah suatu alat yang sangat membantu siswa dalam memecahkan masalah yang berkaitan dengan pengorganisasian ide dan pikiran. Mind mapping membantu mengorganiasikan dan mengingat informasi tertulis, menemukan permasalahan dalam esai, merencanakan dan mengevaluasi tulisan :"mind mapping is seen as a powerful tool to help students overcome problems with the organization of their ideas and thoughts. In addition, it was also found that relating images to concepts is a creative task which requires thinking instead of memorizing". Lebih lanjut lagi, Chan dalam penelitian Imran Mahmud dan Jahidur Rahman (2011) menyebutkan bahwa mind mapping dapat digunakan sebagai suatu strategy pre-writing untuk membantu menentukan dan mengembangkan ide dalam menulis :"mind mapping can be used as a pre-writing strategy to help explore and generate ideas for writing". Beberapa manfaat penerapan teknik mind mapping dalam membantu proses pembelajaran menulis seperti yang dijelaskan oleh Chan adalah : (1) membantu dalam mengorganisasikan ide, (2) membantu memperjelas ide-ide, (3) Membantu menemukan ide yang lebih tepat dan relevan, (4) untuk membantu menuangkan ide dalam paragraf.

Berkaitan dengan pengaruh penerapan teknik mind mapping terhadap kemampuan siswa dalam menuangkan idenya dijelaskan dalam penelitian Rafidah Abdul Karim (2016). Sebanyak $40 \%$ siswa mengalami kenaikan dalam hal mengekspresikan idenya dan mengembangkannya dalam tulisan. Penelitian Irawati Rahman dan Dwi Mutia Chan (2016) juga menghasilkan kesimpulan yang sama bahwa penerapan teknik mind mapping berpengaruh terhadap kemampuan mahasiswa dalam mengorganisasikan ide. Sebanyak 25 orang mahasiswa $(92,6 \%)$ mendapatkan hasil akhir nilai A dan mahasiswa yang mendapatkan nilai B hanya sebanyak 2 orang $(7,4 \%)$ dengan rata-rata kelas sebesar 845,29. 
Sejalan dengan penelitian-penelitian yang sudah dilakukan mengenai pengaruh penerapan teknik mind mapping terhadap kemampuan menulis esai, hasil penelitian Ida Ayu Putri, dkk (2017) menunjukkan bahwa penerapan teknik mind mapping meningkatkan kualitas dan kuantitas esai terutama dalam hal penggunaan penanda koherensi. Kekoherenan esai yang dihasilkan setelah dilakukan penelitian tindakan kelas dengan teknik mind mapping terlihat jelas, terutama pada penggunaan sinyal transisi. Bila sebelumnya nilai rerata aspek koherensi adalah 20,5, maka setelah ada penerapan teknik mind mapping nilai rerata meningkat menjadi 22,1. Bila sebelumnya penggunaan sinyal transisi didominasi oleh kata penghubung "and, but, or", setelah adanya PTK penggunaan frasa transisi bertambah menjadi "however, moreover, furthermore: dan sebagainya.

\section{METODE PENELITIAN}

Penelitian ini menggunakan desain Penelitian Tindakan Kelas (Classroom Action Research) yang akan dilakukan di satu (1) kelas Prodi Sastra Inggris Fakultas Bahasa Unissula Semarang, di mana di prodi tersebut terdapat mata kuliah Essay Writing di semester 3. Penelitian Tindakan Kelas (Classroom Action Research) dilakukan dengan pertimbangan dapat memberikan alternatif teknik pengajaran untuk lebih memacu mahasiswa dalam mengembangkan ide menjadi esai sastra yang utuh dan runtut. Classroom Action Research akan dilakukan dengan membuat model pengajaran dengan teknik mind-mapping sesuai kreativitas mahasiswa dan menerapkannya di satu (1) kelas Prodi Sastra Inggris. Penelitian ini juga mengajak dosen-dosen pengampu mata kuliah Essay Writing untuk ikut serta membuat model mind-mapping yang kreatif dan menarik sebagai media yang dapat lebih memotivasi mahasiswa dalam meningkatkan ketrampilan menulis esai. Kegiatan penelitian ini akan dilaksanakan selama 4 bulan.

Metode pengumpulan data dilakukan melalui pendokumentasian dan observasi.

1. Pendokumentasian dalam hal ini adalah pengumpulan hasil tulisan esai mahasiswa. Pendokumentasian hasil tulisan esai mahasiswa dibagi menjadi 3 tahap, yang pertama adalah tahap pra-tindakan, yaitu tahap awal sebelum dilakukan pengajaran dengan menggunakan teknik mind-mapping), tahap kedua (Siklus I) yaitu tahap diperkenalkannya teknik mindmapping kepada mahasiswa (pendokumentasian latihan-latihan yang dilakukan di dalam kelas dan tugas terstuktur) dan tahap III (Siklus II) yaitu tahap akhir yang berupa hasil ujian akhir semester mahasiswa. Pendokumentasian berfungsi untuk (1) membantu peneliti dalam 
mengumpulkan data mengenai model mind-mapping yang dibuat oleh mahasiswa untuk melihat peningkatan motivasi setelah kreativitas meraka tersalurkan dalam model mindmapping tersebut, (2) membantu peneliti mambuat analisa penerapan teknik mind-mapping terhadap keruntutan dan kelogisan tulisan esai.

2. Observasi digunakan untuk merekam aktifitas yang terjadi di dalam kelas selama penerapan teknik mind-mapping. Observasi yang dilaksanakan berupa field notes. Field notes difokuskan pada aktifitas dosen dan mahasiswa saat memberikan penjelasan mengenai model mind-mapping yang digunakan dalam menyusun dan mengembangkan ide.

Data dalam penelitian ini adalah hasil tulisan esai sastra mahasiswa. Hasil tulisan berupa hasil latihan kelompok di dalam kelas, tugas mandiri, dan hasil tes ujian akhir semester. Data yang dikumpulkan akan dianalisis secara kuantitatif. Terdapat empat (4) indikator penulisan esai sastra yang akan diteliti : 1) Penentuan topik dan judul penelitian, 2) Struktur Esai, yang terdiri dari Pendahuluan, Pembahasan dan Kesimpulan 3) Kelogisan atau Keutuhan (Unity), 4) Keruntutan (Coherence).

Analisis data dilakukan dengan memberikan penilaian dengan skala 1-5 terhadap 4 indikator yang diteliti. Penilaian dilakukan dengan cara memberikan tanda check $(\sqrt{ })$ untuk tiap-tiap indikator sesuai dengan nilai yang dianggap cocok. Skala 1 dimaknai sebagai sangat tidak baik. Skala 2 dimaknai sebagai kurang baik. Skala 3 dimaknai sebagai agak baik. Skala 4 dimaknai sebagai baik, dan skala 5 dimaknai sebagai sangat baik. Hasil perolehan skor akan dijumlahkan dan dibagi dengan jumlah skor maksimum. Nilai perolehan akhir didapat dari jumlah skor perolehan dibagi dengan jumlah skor maksimal untuk kemudian dikalikan 100 .

Nilai perolehan akhir $=\underline{\Sigma \text { skor perolehan }}$ X 100

$\Sigma$ skor maksimal

\section{HASIL DAN PEMBAHASAN}

Pelaksanaan pengajaran esai sastra ini dimulai dengan pemaparan tentang teori dan konsep esai sastra, struktur (pengorganisasian) esai sastra dan penjelasan mengenai kelogisan/keutuhan (unity) dan keruntutan (coherence) dalam esai sastra. Pemaparan mengenai struktur esai sastra dillakukan dengan jumlah pertemuan yang lebih banyak karena struktur esai sastra berbeda dengan struktur esai pada umumya seperti pada esai narasi, deskripsi, eksposisi, argumentasi dan lain-lain. Seperti halnya struktur esai, struktur esai sastra 
juga terdiri dari bagian pendahuluan, bagian pembahasan dan bagian kesimpulan. Bagian Pendahuluan terdiri dari kalimat pemikat (hook) agar pembaca tertarik untuk membaca kesuluruhan isi esai dan latar belakang secara umum yang berkaitan dengan topik yang akan dibahas serta pernyataan thesis (thesis statement) yang berisikan kalimat detil mengenai apa yang akan djelaskan lebih lanjut dalam bagian pembahasan. Bagian Pembahasan terdiri dari pembahasan secara mendetil topik yang dipilih. Bagian Kesimpulan berisikan rangkuman atau kesimpulan dari apa yang telah dijabarkan dalam bagian pembahasan.

Yang membedakan esai sastra dengan esai yang lain adalah di bagian pendahuluan dan bagian pembahasan. Dalam esai sastra, bagian pendahuluan akan berisikan kalimat pemikat (hook), TAG (Title, Author, Genre) yang merupakan penjelasan singkat tentang karya sastra yang akan dibahas, seperti judul karya sastra, pengarang dan jenis karya sastra (puisi, prosa, drama, dll), serta pernyataan tesis (thesis statement). Bagian pembahasan dalam esai sastra akan berisikan kalimat pembuka yang sejalan dengan pernyataan tesis, penjelasan yang dapat berupa referensi, bukti (kutipan yang diperoleh dari karya sastra yang dibahas) serta penjelasan tentang bukti tersebut.

Setelah mahasiswa memahami tentang struktur esai sastra, kelogisan dan keruntutan dalam esai sastra, mahasiswa diberikan pra-tindakan berupa tes menulis esai sastra. Berdasarkan kegiatan tes pra-tindakan, didapatkan hasil bahwa kemampuan mahasiswa menulis esai sastra masih sangat rendah. Dari 19 mahasiswa yang mengambil mata kuliah Esaibased Writing, tidak ada satupun mahasiswa yang mendapatkan nilai 85 (A), sebanyak 2 orang mahasiswa mendapatkan nilai 75-84 (AB), sebanyak 3 orang mahasiswa mendapatkan nilai 6574 (B), sebanyak 5 orang mahasiswa mendapatkan nilai 60-64 (BC), sebanyak 5 orang mahasiswa mendapatkan nilai 50-59 (C) dan sebanyak 4 orang mahasiswa mendapatkan nilai dibawah $50(\mathrm{CD})$.

Tabel 1. Distribusi Frekuensi Nilai Ketrampilan Menulis Esai Sastra Pra-Tindakan

\begin{tabular}{|c|c|c|c|}
\hline Interval & Bobot & $\begin{array}{c}\text { Frekuensi } \\
\text { (Jumlah Mahasiswa) }\end{array}$ & Presentase (\%) \\
\hline $85-100$ & $\mathrm{~A}$ & 0 & 0 \\
\hline $75-84$ & $\mathrm{AB}$ & 2 & 11 \\
\hline $65-74$ & $\mathrm{~B}$ & 3 & 16 \\
\hline
\end{tabular}




\begin{tabular}{|c|c|c|c|}
\hline $60-64$ & BC & 5 & 26 \\
\hline $50-59$ & $\mathrm{C}$ & 5 & 26 \\
\hline $40-49$ & $\mathrm{CD}$ & 4 & 21 \\
\hline $30-39$ & $\mathrm{D}$ & 0 & 0 \\
\hline Jumlah & & 19 & $100 \%$ \\
\hline
\end{tabular}

Sejalan dengan data tersebut, dari 4 indikator yang nilai menunjukkan bahwa sebanyak 16 mahasiswa masih merasa kesulitan dalam penentuan topik, 14 orang mahasiswa masih mempunyai kendala dalam menulis struktur esai, dalam hal ini kendala terbesar adalah penulisan bagian pendahuluan. Kendala yang dihadapi selanjutnya adalah mengembangkan topik ke dalam bagian pembahasan. Hal ini terbukti dari 11 orang mahasiswa yang menuliskan kalimat dan paragraf yang tidak sesuai dengan topik maupun pernyatan tesis. Kendala terakhir yang didapatkan adalah penggunaan kata atau kalimat penghubung (transition sentence) yang sesuai sehingga antara kalimat satu dengan yang lain runtut dan logis. Hal ini tercermin dari data 8 orang mahasiswa.

Pelaksanaan pengajaran selanjutnya dilakukan dengan penjelasan tentang konsep mindmapping dan langkah-langkah pembuatan mind-mapping. Pembuatan mind-mapping ini dilakukan dengan mempertimbangkan referensi yang diperoleh setelah mahasiswa mempunyai beberapa pilihan topik/ide yang sesuai dengan karya sastra yang dibahas. Dalam pertemuan tersebut dosen memberikan contoh model mind-mapping dalam membahas suatu karya sastra. Model tersebut diharapkan membantu mahasiswa dalam mencerna penggunaan teknik mindmapping tersebut. Berikutnya adalah pemberian latihan pembuatan mind-mapping secara berkelompok dengan objek karya sastra yang dipilihkan dosen. Setiap kelompok diberikan kesempatan untuk mendiskusikan dan kemudian menyampaikan topik esai dan pernyataan tesisnya. Mahasiswa terbukti cukup antusias mengerjakan tugas yang diberikan.

Setelah mendapatkan koreksi dan saran dari dosen tentang mind-mapping yang sudah ditulis, mahasiswa secara berkelompok diminta untuk menulis draft esai. Draft tersebut akan dikumpulkan untuk kemudian dikoreksi kembali oleh dosen dengan mempertimbangkan indikator yang selanjutnya yaitu tentang keutuhan dan keruntutan esai. Ketika jam perkuliahan selesai, dosen akan membagikan tugas membuat mind-mapping secara individu. Tugas tersbut akan dijadikan sebagai data Siklus I (setelah mahasiswa diberikan pemaparan tentang teknik mind-mapping). Hasil dari Siklus I disajikan pada table 2 di bawah ini. 
Tabel 2. Distribusi Frekuensi Nilai Ketrampilan Menulis Esai Sastra Siklus I

\begin{tabular}{|c|c|c|c|}
\hline Interval & Bobot & $\begin{array}{c}\text { Frekuensi } \\
\text { (Jumlah Mahasiswa) }\end{array}$ & Presentase (\%) \\
\hline $85-100$ & $\mathrm{~A}$ & 2 & 11 \\
\hline $75-84$ & $\mathrm{AB}$ & 3 & 16 \\
\hline $65-74$ & $\mathrm{~B}$ & 5 & 26 \\
\hline $60-64$ & $\mathrm{BC}$ & 4 & 21 \\
\hline $50-59$ & $\mathrm{C}$ & 4 & 5 \\
\hline $40-49$ & $\mathrm{CD}$ & 1 & 0 \\
\hline $30-39$ & $\mathrm{D}$ & 0 & $100 \%$ \\
\hline Jumlah & & 19 & 21 \\
\hline
\end{tabular}

Berdasarkan Siklus I di atas, didapatkan hasil bahwa kemampuan mahasiswa menulis esai sastra meningkat meskipun relatif kecil karena masih ada sekitar 5 orang mahasiswa yang mendapatkan hasil minimal (C dan $\mathrm{CD}$ ). Dari 19 mahasiswa ada satu mahasiswa yang mendapatkan nilai 85 (A), sebanyak 3 orang mahasiswa mendapatkan nilai 75-84 (AB), sebanyak 5 orang mahasiswa mendapatkan nilai 65-74 (B), sebanyak 4 orang mahasiswa mendapatkan nilai 60-64 (BC), sebanyak 4 orang mahasiswa mendapatkan nilai 50-59 (C) dan sebanyak 1 orang mahasiswa mendapatkan nilai 45 (CD).

Kendala yang dihadapi oleh mahasiswa berdasarkan dari 4 indikator yang ditentukan berbeda dari Pra-Tindakan, di mana mahasiswa masih merasa kesulitan dalam penentuan topik menurun menjadi 8,9 orang mahasiswa masih mempunyai kendala dalam menulis struktur esai, dalam hal ini kendala terbesar berada pada bagian pembahasan. Mahasiswa kesulitan dalam menjelaskan hubungan antara bukti yang di dapat dari karya sastra dengan referensi yang diperoleh. Kendala selanjutnya adalah penggunaan kata atau kalimat penghubung (transition sentence) yang sesuai sehingga antara kalimat satu dengan yang lain runtut dan logis. Hal ini tercermin dari data 4 orang mahasiswa.

Meskipun terjadi peningkatan kemampuan mahasiswa dalam penulisan esai sastra, khususnya berkaitan dengan penentuan topik esai dan penulisan struktur esai, tetapi hal ini membuktikan bahwa tindaka pada siklus I belum optimal karena belum mencapai hasil sesuai yang diharapkan. Oleh karena itu dilakukan tindakan di Siklus II yang berupa penekanan 
kembali dengan memperbanyak latihan baik secara mandiri maupun kelompok, khususnya yang berkaitan dengan cara mengembangkan topik esai ke dalam paragraf pembahasan. Mahasiswa diminta kembali untuk mencari referensi yang sesuai dan berlatih menuangkan referensi yang di dapat ke dalam kalimat yang sesuai dengan bukti dalam karya sastra. Dengan referensi yang bertambah maka cabang dari mind-mapping akan semakin banyak sehingga mahasiswa akan dapat lebih luas lagi mengembangkan paragraf pembahasan. Setelah dilakukan tindakan pada Siklus II, terjadi peningkatan yang cukup signifikan terhadap kemampuan mahasiswa dalam mengembangkan paragraf dalam esainya. Distribusi frekuensi peningkatan nilai ketrampilan mahasiswa menulis esai pada Siklus II tampak pada table 3 di bawah ini.

Tabel 3. Distribusi Frekuensi Nilai Ketrampilan Menulis Esai Sastra Siklus II

\begin{tabular}{|c|c|c|c|}
\hline Interval & Bobot & $\begin{array}{c}\text { Frekuensi } \\
\text { (Jumlah Mahasiswa) }\end{array}$ & Presentase (\%) \\
\hline $85-100$ & $\mathrm{~A}$ & 4 & 21 \\
\hline $75-84$ & $\mathrm{AB}$ & 7 & 36 \\
\hline $65-74$ & $\mathrm{~B}$ & 4 & 21 \\
\hline $60-64$ & $\mathrm{BC}$ & 2 & 11 \\
\hline $50-59$ & $\mathrm{C}$ & 2 & 0 \\
\hline $40-49$ & $\mathrm{CD}$ & 0 & 0 \\
\hline $30-39$ & $\mathrm{D}$ & 0 & $100 \%$ \\
\hline Jumlah & & 19 & \\
\hline
\end{tabular}

Hasil Siklus II di atas menunjukkan hasil kemampuan mahasiswa menulis esai sastra meningkat cukup signikan dengan adanya 4 orang mahasiswa yang mendapatkan hasil maksimal A. Dari 19 mahasiswa 4 satu mahasiswa yang mendapatkan nilai 85 (A), sebanyak 7 orang mahasiswa mendapatkan nilai 75-84 (AB), sebanyak 4 orang mahasiswa mendapatkan nilai 65-74 (B), sebanyak 2 orang mahasiswa mendapatkan nilai 60-64 (BC), sebanyak 2 orang mahasiswa mendapatkan nilai 50-59 (C) dan tidak ada lagi mahasiswa yang mendapatkan nilai di bawah 50 (CD). Kendala yang dihadapi oleh mahasiswa berdasarkan dari 4 indikator yang ditentukan juga tampak berbeda dari Siklus I, di mana mahasiswa yang masih merasa kesulitan dalam penentuan topik menurun menjadi 2,2 orang mahasiswa masih mempunyai kendala dalam menulis struktur esai, dalam hal ini kendala terbesar berada pada bagian pembahasan dan 
penggunaan kata atau kalimat penghubung (transition sentence) yang sesuai sehingga antara kalimat satu dengan yang lain runtut dan logis.

Peningkatan kemampuan mahasiswa dalam menulis esai, khususnya peningkatan kemampuan penentuan topik esai dan mengembangkan topik ke dalam struktur esai membuktikan bahwa pengajaran penulisan esai dengan teknik mind-mapping dapat membantu mahasiswa berlatih menemukan ide dan mengungkapkan dengan cara mengembangkan menjadi beberapa paragraf yang utuh dan runtut.

\section{KESIMPULAN}

Berdasarkan pembahasan hasil penelitian yang dilakukan pada tiga tahap yang berbeda (tahap Pra-Tindakan, Siklus I dan Siklus II), dapat disimpulkan bahwa pengajaran menulis esai sastra dengan penggunaan teknik mind-mapping terbukti berpengaruh dalam peningkatan kemampuan menulis esai sastra mahasiswa program studi Sastra Inggris Fakultas Bahasa dan Ilmu Komunikasi Unissula Semarang. Dengan latihan membuat mind-mapping suatu karya sastra baik secara berkelompok maupun secara individu ternyata dapat meningkatkan nilai ketrampilan menulis esai sastra. Kebebasan mahasiswa dalam mencari dan menemukan ide esai dengan diarahkan dan dikoreksi oleh dosen terbukti mampu merangsang mahasiswa untuk lebih kreatif dan percaya diri dalam mengembangkan ide kreatifnya.

\section{DAFTAR PUSTAKA}

Abdul Ghani Abu, Rafidah Abd Karim and Mohd Khaja, Farah Natchiar. 2016. Brainstorming Approach and Mind Mapping in Writing Activity. Proceedings of the 1st English Education International Conference (EEIC) in conjunction with the 2nd Reciprocal Graduate Research Symposium (RGRS) of the Consortium of Asia-Pacific Education Universities (CAPEU) between Sultan Idris Education University and Syiah Kuala University. November 12-13, 2016, Banda Aceh, Indonesia.

Ferheen Bukhari, Seyda Saima. 2017. "Mind mapping Techniques to Enhance EFL Writing Skill". International Journal of Linguistics and Communication. June 2016, Vol. 4, No.1, pp. 58-77.

Gita Ardiantari, Ida Ayu Putri, dkk. 2017. Peningkatan Kualitas Koherensi Esai Melalui Mind-Mapping. Journal of Language and Translator Studies. Vol. 3, No.5. Februari 2017. 
Pujiono, Setyawan. 2011. Penerapan Strategi Catalisting untuk Meningkatkan Kemampuan Menulis Esai. Jurnal Penelitian Bahasa, Sastra dan Pengajarannya : LITERA, Vol 10 (02).

Rahman, Irawati dan Mutia Chan, Dwi. 2016. Penerapan Metode Peta Pikiran dalam Menulis Esai Mahasiswa Semester V STKIP YDB Lubuk Alung. Ta'dib, Volume 19, No.1 (Juni 2016).

Rasyidah, Ummi dan Antoni, Rivi. 2014. Analisis Kemampuan Mahasiswa Pendidikan Bahasa Inggris Semester VI Universitas Pasir Pengaraian dalam Menulis Critical Essay. Jurnal Ilmiah Edu Research, Vol.3 No.1 Juni 2014

Shahriar Rawshon, Imran Mahmud and Rahman, Jahidur Md. 2011. Mind Map for Academic Writing : A Tool to facilitate University Level Students. International Journal of Educational Science and Research, Vol. 1, Issue 1 (2011) pp. 21-30. 